Int. J. Dev. Biol. 60: 201-207 (2016)

doi: $10.1387 / \mathrm{ijdb} .160142 \mathrm{jb}$

\title{
Xenopus cell-free extracts and their contribution to the study of DNA replication and other complex biological processes
}

\author{
J. JULIAN BLOW*,1 and RONALD A. LASKEY² \\ ${ }^{1}$ School of Life Sciences, University of Dundee, Dundee and \\ ${ }^{2}$ Department of Zoology, University of Cambridge, Cambridge, UK
}

\begin{abstract}
Here we discuss the important contributions that cell-free extracts have made to the study of complex biological processes. We provide a brief history of how cell-free extracts of frog eggs were developed to avoid many of the problems that can arise from the dilution and mixing of cellular components that typically occur when cell-free extracts are prepared. We briefly describe how Xenopus egg extracts have been fundamental to the study of many important cellular processes including DNA replication, cell cycle progression, nuclear protein import, nuclear assembly and chromosome organisation. We describe how, in particular, Xenopus egg extracts have made a major contributions to the study of DNA replication, by permitting the direct manipulation of proteins in a system that is extraordinarily faithful to the way that DNA replication occurs in the living embryo. Finally we consider how results obtained using Xenopus egg extracts are being translated to produce diagnostic reagents for cancer screening and diagnosis.
\end{abstract}

KEY WORDS: Xenopus, frog, egg, cell-free extract, in vitro, DNA replication

\section{Why are cell-free extracts valuable?}

Cell-free extracts have played important roles for many decades in both biochemistry and cell biology. An early and fundamental use of cell-free extracts was to provide the starting point for the purification of individual biochemical activities. This was typically achieved by following the biochemical activity whilst the extract was fractionated over several different chromatographic purification steps until only one protein remained. Nowadays cell extracts are frequently made as a starting point for analysis of protein and nucleic acids using any of the highly sensitive techniques available to molecular biologists, such as immunoblotting, mass spectrometry or DNA sequencing. The only major constraint on using extracts in these ways is that the components under study should remain intact and present during preparation of the extract and for example do not become degraded or insoluble.

Cell extracts are also a very powerful way of examining the potential interaction between cellular components in more complex biological systems. To address this sort of question, a typical approach is to prepare a cell lysate, and then use an affinity or fractionation step - commonly immunoprecipitation - to examine a potential physical interaction between two components such as the presence of a protein complex or the binding of proteins to DNA. The pitfalls of these types of experiment are well-known but not always avoided. For example inappropriate buffers used in making the lysate can force proteins together or separate them, so that the interactions occurring in the lysate are not those that occur in vivo. One reason why proteins might associate in a cell extract but not in vivo is that if they normally occur in different subcellular compartments that are mixed during extract preparation, they might encounter one another in a way that would not be possible in vivo.

Another major use for cell-free extracts, which is the main focus of the current review, is to examine the behaviour of complex systems that depend on the interaction of many different factors. The cell-free extract allows the identification and experimental manipulation of different components of the system in a way that is not possible in a living cell. Extracts have been used in this way to study many important biological processes, including transcription, translation, DNA replication, nuclear organisation and membrane trafficking. Cell-free extracts that perform these complex functions have to be prepared with great care in order to maintain the many activities involved, and this means that there are often a limited number of extract systems available to study a particular process. This review will emphasise in more detail the use cell-free extracts of Xenopus eggs and oocytes for the analysis of complex systems that depend on the interplay of many different factors, such as DNA replication.

One of the most successful early uses of mammalian cell-free

*Address correspondence to: J. Julian Blow. School of Life Sciences, University of Dundee, Dundee DD1 5EH, UK. E-mail: j.j.blow@ dundee.ac.uk

Accepted: 4 May 2016.

ISSN: Online 1696-3547, Print 0214-6282 
extracts was for the study of protein synthesis and its control (Mathews and Korner, 1970; Pelham and Jackson, 1976). These studies resulted in identification of initiation factors and elongation factors for protein synthesis as well as identification of messenger RNAs. Reticulocyte lysates continued to make valuable contributions to these areas during the 1970s and 1980s. Ironically, a major challenge to their use for assaying mRNAcame from microinjection studies using Xenopus oocytes (Gurdon et al., 1971). Because of their large size and availability in large numbers, eggs and oocytes of the frog Xenopus laevis have made important contributions to answering a wide range of questions in cell and developmental biology. The areas of their successes include control of the cell cycle and mechanism of cell cycle components, control of DNA synthesis and identification of components involved, assembly of chromatin and of the cell nucleus, and transport of macromolecules between the cytoplasm and the nucleus (see below).

\section{Constraints on cell-free extracts}

In order for it to be a valuable tool for studying a complex process, a cell-free extract should support the process under study in a way that mimics as closely as possible what happens in the intact cell. This is often hard to achieve. To make the extract 'cell-free' so that components can easily be manipulated, the very minimum is that the plasma membrane has to be ruptured or dissolved. This is typically achieved by using detergents or by mechanical forces, both of which may then lyse or disrupt structures or protein complexes within the cell that are important for the process under study. Cells are highly organised structures, containing many insoluble or large structures that co-ordinate biological activities, such as mitochondria, endoplasmic reticulum, Golgi or the nucleus. When making an extract, the consequences of eliminating these structures (eg mixing cytoplasm and nucleoplasm) need to be clearly appreciated. To make a soluble extract, proteins often need to be removed or eluted from larger structures so that they become available for experimental investigation. For example, in order to study transcription factors or other DNA-bound proteins, they may need to be eluted from chromatin into the extract, unless the cell has a large excess of these proteins free in the cytoplasm or nucleoplasm. The interior of a cell is a densely-packed jumble of proteins, nucleic acids and other macromolecules in very close proximity to each other with very little free water. In typical cell extracts, however, the cellular components are significantly diluted when compared to the intact cell, which can have profound implications for the ability for some complex processes to proceed. A good example of this is nuclear assembly in Xenopus egg extracts, the efficiency of which is highly sensitive to dilution. The dilution that occurs when cell-free extracts are made introduces an ionic aqueous environment that can be very different from that of the intact cell. This can have profound effects on complex biological reactions, so the components of the diluting buffer need to be chosen with care. For example, whilst the physiological intracellular cation is potassium at $150 \mathrm{mM}$, the main intracellular anion comes from negatively-charged amino acids on proteins and the concentration of chloride is much lower than that of potassium (10-80 mM, varying between cell types). In cell-free extracts, chloride is typically added to buffers at concentrations higher than exist in vivo, and is inhibitory to many reactions. For example, concentrations of chloride above $\sim 75 \mathrm{mM}$ disrupt the Mcm2-7 heterohexamer and prevent it being loaded onto DNA in the licensing step of DNA replication.

\section{Value of Xenopus eggs for making cell-free extracts}

Xenopus eggs have been extraordinarily valuable for a range of studies using cell-free extracts (Fig. 1). One crucial advantage of Xenopus eggs or oocytes as sources of cell-free extracts has been the ease of microinjecting molecules into the intact cell to guide in vitro, cell-free, studies and to validate the results that emerge from them. Cell-free assays have a major advantage over microinjection studies in that they facilitate fractionation by providing more convenient assays for fractionated molecules. However, microinjection provides a gold standard for validating cell-free results.

Eggs are large single cells and therefore easy to lyse without extraction components such as detergents that are potentially inhibitory. Furthermore they can be lysed gently by centrifugation minimising the shear forces involved in mechanical homogenisation procedures. Centrifugation also provides a convenient means of sub-cellular fractionation of the resulting homogenates. The large maternal stockpile of materials required for rapid cell division and development following fertilisation provides rich sources of enzymes and regulatory factors. Proteins involved in cell proliferation are extremely well represented. This same stockpile means that only minimal transcription and translation are required for the rapid series of cell divisions that follow fertilisation. Therefore these pre-packaged cell division machines have been particularly valuable in studies of various aspects of cell proliferation and basic cell biology, though their value for studying gene expression has been more limited.

Early attempts at homogenising Xenopus eggs and oocytes to make cell-free extracts were made in the mid-1970s (Benbow and Ford, 1975; Gandini Attardi et al., 1976; Mattoccia et al., 1976). Benbow and Ford added Xenopus liver nuclei to eggs that had been homogenised in a blender and observed tritiated dTTP incorporation as well as possible replication bubbles in the electron microscope (Benbow and Ford, 1975). Gandini Attardi added SV40 DNA to oocyte extract and observed complex forms in the electron microscope which they interpreted cautiously as the products of either replication or recombination (Gandini Attardi et al., 1976). Mattocia et al., used the same procedures as Gandini Attardi and fractionated a relaxing activity which we would now

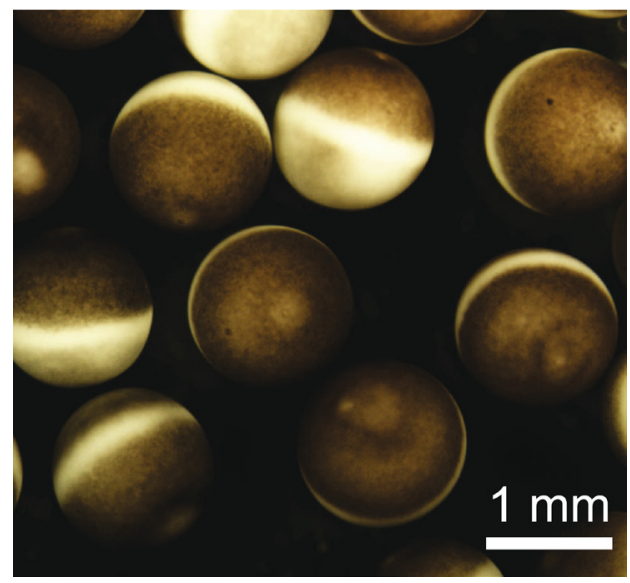

Fig. 1. Xenopus eggs. A photograph of de-jellied Xenopus laevis eggs. Scale bar, $1 \mathrm{~mm}$. Courtesy of Jolanta Kisielewska, University of Plymouth. 

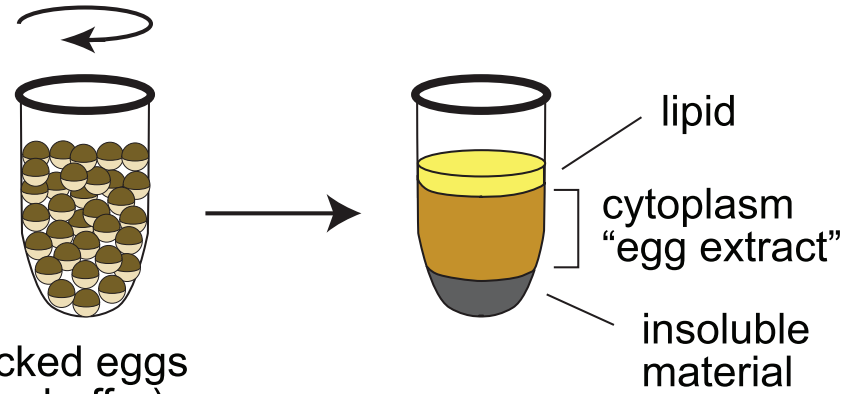

zling problem encountered in these early studies of nucleosome assembly by nucleoplasmin or the combination of nucleoplasmin with N1/N2 (Kleinschmidt and Franke, 1982; Kleinschmidt et al., 1985; Dilworth et al., 1987) was its relatively slow assembly rate compared to the extremely short cell cycles of early embryos. This paradox was resolved by the discovery that DNA replication accelerated chromatin assembly in egg extracts substantially (Gaillard et al., 1996).

Studies of nucleoplasmin had two important spin-offs. First they revealed that nucleoplasmin has an important role in decondensing sperm chromatin at fertilisation (Ohsumi and Katagiri, 1991; Philpott et al., 1991; Philpott and Leno, 1992; Leno et al., 1996). Second, attempts to confirm that nucleoplasmin was indeed a nuclear protein produced the initially controversial result that import of nuclear proteins into the nucleus is not by free diffusion and selective retention of only nuclear proteins as was previously thought, but was by signal mediated selective import of only nuclear proteins (Dingwall et al., 1982; Robbins et al., 1991). The initial studies of nucleoplasmin import into nuclei were made by microinjection of proteins and protein fragments into the cytoplasm or the nucleus of intact oocytes. However, fractionation to identify the import factors called importins or karyopherins was made from egg extract, using permeabilised mammalian cells as the nuclear targets for import (Gorlich et al., 1994; Gorlich et al., 1995b; Gorlich et al., 1995a).

Amphibian egg extracts were exceptionally important in analysing the control of the cell cycle and the assembly of nuclear structures after mitosis. Lohka and Masui made critically important contributions to analysing the control of the cell cycle. Initially they used cell-free extracts from eggs of the frog Rana pipiens, though in subsequent studies they used Xenopus as the source of eggs. They introduced several crucial procedures that increased the value of egg extracts dramatically (Fig. 2) (Lohka and Masui, 1983). First, they avoided conventional homogenisation, but instead they lysed eggs by centrifugation of packed eggs. Secondly, the extracts contained very little exogenous buffer and so maintained cellular components at near physiological concentrations. Thirdly, they took steps to exclude calcium from homogenisation buffers and by including EGTA they were also able to counteract the enwere identified by fractionation of Xenopus egg extracts. A puz-

A

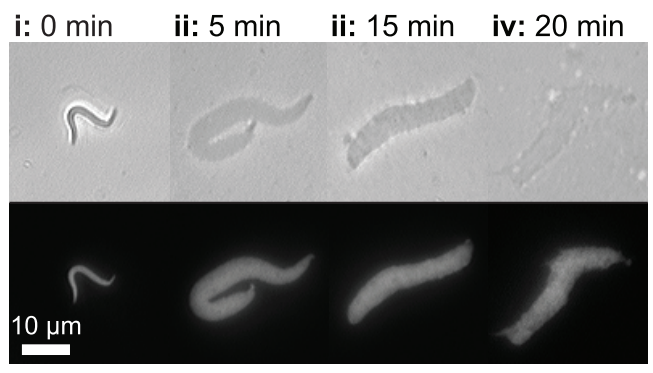
egg extracts. Sperm nucleiwere incubated in metaphase arrested Xenopus egg extract released into interphase by addition of $0.3 \mathrm{mM} \mathrm{CaCl}$. (A) Nuclear formation was followed over the course of 60 minutes by phase contrast (upper panels) and UV (lower panels) microscopy (i-vii). Sperm nuclei incubated in extract in the absence of $\mathrm{CaCl} 2$ were visualized after 60 minutes (viii). Bar, $10 \mu \mathrm{m}$. (B) DNA synthesis was followed over the course of the incubation by measuring incorporation of $\left[\alpha^{32} P\right]-d A T P$. Reproduced from (Gillespie et al., 2012).
B

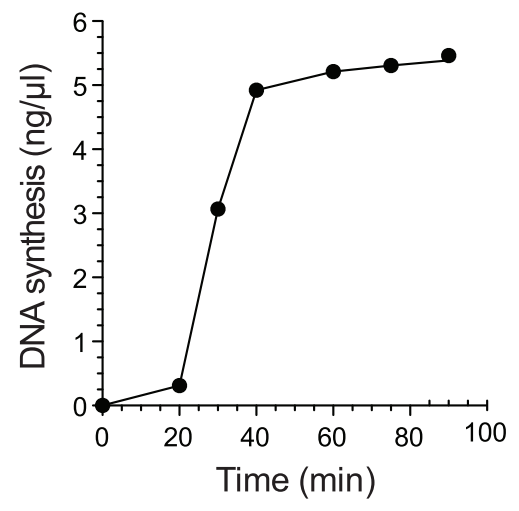


dogenous calcium in the extract, thereby preventing spontaneous release from cell cycle arrest in meiotic metaphase II (Lohka and Masui, 1984a). Furthermore they used low speed supernatants rather than taking only the soluble fraction. Indeed they showed that both the soluble fraction and a particulate membrane fraction were required for maximum activity in the systems (Lohka and Masui, 1983, 1984b). When these three procedures were followed they obtained extracts that were capable of decondensing sperm chromatin, assembling the chromatin into nuclei and then allowing DNA synthesis, which others subsequently showed was genuine semi-conservative replication (Fig. 3) (Blow and Laskey, 1986; Blow and Watson, 1987). The nuclei were subsequently disassembled and the chromatin condensed as the extracts entered mitosis in vitro. When protein synthesis was blocked so that extracts could not enter mitosis, these extracts supported exactly one round of DNA replication as evidenced by density substitution (Blow and Laskey, 1986) and flow cytometry (Blow and Watson, 1987) experiments, suggesting that the DNA replication was occurring under normal cell cycle control. Egg extracts prepared by the principles of Lohka and Masui appear to faithfully support all of the cytoplasmic activities that occur in the early embryo and which do not require the plasma membrane. This means that they essentially represent a 'cell in a test tube'. As a consequence, Xenopus egg extracts have been widely exploited for the study of many further processes including nuclear assembly, nuclear cytoplasmic transport, DNA repair, and chromosome structure. Perhaps the most important application of Lohka and Masui's egg extracts was the isolation by Lohka and Maller of maturation promoting factor or MPF (Lohka et al., 1988; Gautier et al., 1988). This elusive factor had been a 'holy grail' of cell cycle studies and its isolation allowed integration of the whole cell cycle field when it was shown that MPF consisted of a cyclin, complexed to a cyclin-dependent kinase (Gautier et al., 1990). Both activities had been discovered previously but their relationship to one another, and their roles in the cell cycle, became very much clearer when they were identified as the two sub-units of MPF.

\section{The study of DNA replication in Xenopus egg extracts}

Lohka and Masui's extracts also allowed rapid progress in analysis of the control of DNA replication in higher eukaryotes. Previously Mechali and Harland had shown that homogenates of Xenopus eggs were capable of synthesising a complete complementary DNA strand on single stranded DNA templates (Mechali and Harland, 1982). However, they were unable to obtain initiation of DNA replication de novo on double stranded templates. Adoption of Lohka and Masui's extract preparation procedures allowed clear demonstrations of the initiation of DNA replication in vitro (Blow and Laskey, 1986; Blow and Watson, 1987). Since then Xenopus egg extracts have played an important part in many fundamental discoveries about the control of DNA replication.

An early discovery was that the initiation of DNA replication depended on the template DNA being assembled into a functional interphase nucleus supporting active nuclear import (Blow and Watson, 1987; Newport, 1987; Sheehan et al., 1988; Blow and Sleeman, 1990; Cox, 1992). Further work led to a model whereby re-replication of DNA was prevented by there being two nonoverlapping phases that are required for DNA replication: prior to nuclear envelope formation, future origins of replication are 'licensed' for a single initiation event, but once the nucleus was assembled licensed origins could initiate but no further origin licensing could occur (Blow and Laskey, 1988). These principles were further used to identify double hexamers of $\mathrm{Mcm} 2-7$ as the proteins that are assembled onto origins to license them for replication (Chong et al., 1995; Kubota et al., 1995; Madine et al., 1995; Kubota et al., 1997; Gambus et al., 2011). Subsequent work led to the identification of all the proteins necessary to license origins in vitro and a reconstitution of the licensing reaction with purified proteins (Carpenter et al., 1996; Coleman et al., 1996; Romanowski et al., 1996; Rowles et al., 1996; Maiorano et al., 2000; Gillespie et al., 2001). The role of the nuclear envelope in preventing re-replication of DNA was subsequently explained by nuclear import regulating the activity of geminin, a potent inhibitor of the licensing reaction (McGarry and Kirschner, 1998; Tada et al., 2001; Hodgson et al., 2002; Li and Blow, 2005).

Other work on the initiation of replication in Xenopus egg extracts has elucidated the role of $\mathrm{S}$ phase $\mathrm{Cdks}$ and the Cdc7 kinase in replication initiation (Blow and Nurse, 1990; Fang and Newport, 1991; Jares and Blow, 2000; Walter, 2000), has shown how otherwise dormant replication origins can be activated to allow completion of replication under conditions of replicative stress (Woodward et al., 2006) and has led to the identification and analysis of key proteins involved in replication initiation and replisome function, including Treslin, RecQ4 and the GINS complex (Kubota et al., 2003; Kumagai et al., 2010; Sangrithi et al., 2005). Technology for using Xenopus egg extracts to study DNA replication has also developed since the initial protocol of Lohka and Masui. Of note is the development of 'nucleoplasmic extract' (NPE) which provides an extract that can support the initiation of DNA replication without the DNA having to be assembled into a nucleus (Walter et al., 1998). The preparation of NPE exploits the fact that intact nuclei float in Xenopus egg extract. When extracts containing nuclei are centrifuged, a layer of nuclei floats to the top and can be harvested and subsequently crushed to release an undiluted extract of nucleoplasmic protein
Fig. 4. Nucleoplasmic extract cartoon of the method of making 'Nucleoplasmic Extract' from Xenopuseggs according to the original protocol of Walter and Newport. Sperm chromatin is incubated in standard 'low speed supernatants' (prepared as shown in Fig. 2) allowing the assembly of interphase nuclei. The extract is then gently centrifuged $(\sim 16,000$ g) to allow the nuclei to float to the top of the extract. Nuclei are then aspirated from the top, put into a new tube and centrifuged hard ( 250,000 g) to break the nuclei, releasing the soluble 'Nucleoplasmic Extract'.

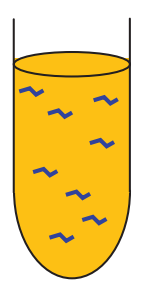

Egg extract + sperm chromatin

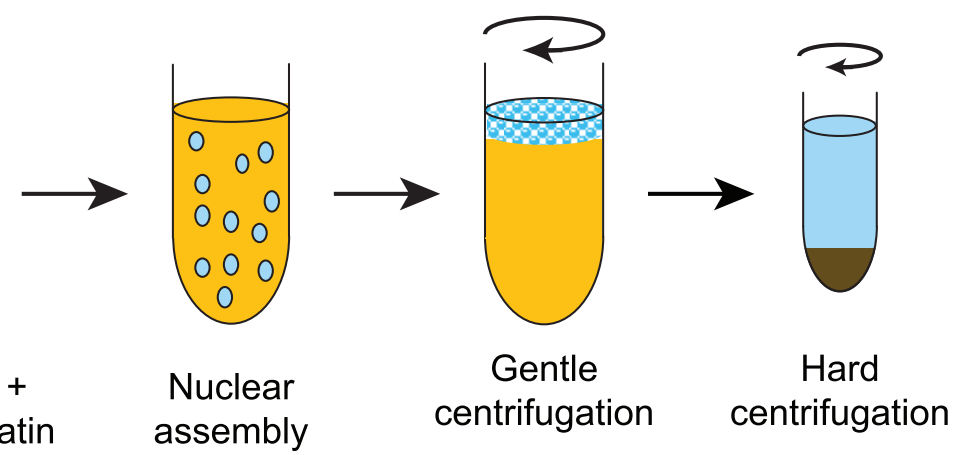


(Fig. 4). When DNA that has already been licensed is incubated in NPE (which contains active geminin and so does not support origin licensing), the initiation of DNA replication occurs very efficiently. The use of NPE provides a powerful extract system for studying replication where there is great control over the different stages of replication and which has allowed the detailed study of processes that are otherwise intractable, such as replication termination (Dewar et al., 2015).

\section{DNA replication in cell-free systems from other species}

In addition to Xenopus egg extracts, cell-free extracts from other systems have also been valuable for studying DNA replication. For example an in vitro system that supports DNA replication has recently been developed in budding yeast (Heller et al., 2011; Gros et al., 2014; On et al., 2014), and using this system replication initiation has recently been achieved using purified proteins (Yeeles et al., 2015). This opens opportunities to generate more mechanistic detail on the initiation process itself.

Efficient initiation of DNA replication in extracts of mammalian cells has been more difficult to achieve, though there has been significant progress in several areas. The first evidence of initiation in mammalian cell-free extracts was achieved using G1 nuclei in S-phase cytoplasm from HeLa cells resulting in cyclin/ Cdk dependent initiation of replication in vitro, though efficiencies were not high and optimisation of the systems has been difficult (Krude et al., 1997). A variation of this system using mouse nuclei released from quiescence as the templates was able to discriminate distinct roles of Cyclin A/Cdk2 and Cyclin E/Cdk2 establishing a sequence of requirements for these two complexes and implicating Cdc6 as an important substrate for their activity (Coverley et al., 2002). A significant improvement was made by simplifying the synchronisation procedures by the use of mimosine and this has allowed exciting recent advances in mapping origins at which human DNA replication initiates. (T. Krude personal communication. Manuscript submitted).

\section{The future of Xenopus egg extracts}

There are still many complex processes that are not well understood and that can be addressed using Xenopus egg extracts. Important work continues to be done on the process of nuclear envelope and nuclear pore assembly, where a huge number of proteins need to be brought together to form a large macromolecular assembly. The Xenopus system has the disadvantage that it is not amenable to genetic analysis, which means that proteins need to be identified using antibodies rather than tags. However, a range of new technologies can be applied to their study. For example, mass spectrometry provides a powerful way to identify proteins in large ultrastructures, such as nuclear pores, replisomes, and chromosomes that can be assembled in vitro and then carefully separated for analysis of their contents (Gambus et al., 2011; Gillespie et al., 2012). There are now a large number of procedures that can be used to create and control cell cycle synchrony in egg extracts with unprecedented precision (Gillespie et al., 2016). Xenopus egg extracts can be used for live microscopy imaging, and in future this approach could be developed to deliver large amounts of data and 'high content' analysis of processes that can be followed by fluorescently marked components. As the acquisition of data becomes more and more powerful, a major challenge for $21^{\text {st }}$ century biology is to understand all of the data that is produced. Cell-free systems, such as Xenopus egg extracts that support complex biological procedures should have a large potential in making sense of biological complexity by allowing scientists to disassemble, reassemble and manipulate highly controlled reactions that involve the interplay between many interacting components.

\section{Translation of results from cell-free systems to produce diagnostic reagents for cancer screening and diagnosis}

Proteins whose roles have been identified using cell-free extracts have emerged as powerful markers for cancer diagnosis and screening. Initial attempts focused on Cdc6 as a potential marker but its stability limited its value. In contrast MCM proteins of the MCM2-7 complex are robust and informative markers that have been tested extensively for both screening and differential diagnosis for a range of cancers (Baldwin et al., 2003; Coleman et al., 2006; Jackson et al., 2013). Clinical trials have been undertaken or are in progress to assess the value of antibodies against MCM2-7 in screening for cancer of the cervix, bladder, prostate, oesophagus and colon amongst other sites. One diagnostic product has already been launched and another is due to be launched later in 2016. These developments are direct consequences of studies using cell-free systems to study DNA replication in both frog and human systems.

\section{References}

BALDWIN, P., LASKEY, R. and COLEMAN, N. (2003). Translational approaches to improving cervical screening. Nat Rev Cancer 3: 217-226.

BENBOW, R.M. and FORD, C.C. (1975). Cytoplasmic control of nuclear DNA synthesis during early development of Xenopus laevis: a cell-free assay. Proc Natl Acad Sci USA 72: 2437-2441.

BLOW, J.J. and LASKEY, R.A. (1986). Initiation of DNA replication in nuclei and purified DNA by a cell-free extract of Xenopus eggs. Cell 47: 577-587.

BLOW, J.J. and LASKEY, R.A. (1988). A role for the nuclear envelope in controlling DNA replication within the cell cycle. Nature 332: 546-548.

BLOW, J.J. and NURSE, P. (1990). A cdc2-like protein is involved in the initiation of DNA replication in Xenopus egg extracts. Cell 62: 855-862.

BLOW, J.J. and SLEEMAN, A.M. (1990). Replication of purified DNA in Xenopus egg extract is dependent on nuclear assembly. J Cell Sci 95: 383-391.

BLOW, J.J. and WATSON, J.V. (1987). Nuclei act as independent and integrated units of replication in a Xenopuscell-free DNA replication system. EMBO J6: 1997-2002.

CARPENTER, P.B., MUELLER, P.R. and DUNPHY, W.G. (1996). Role for a Xenopus Orc2-related protein in controlling DNA replication. Nature 379: 357-360.

CHONG, J.P., MAHBUBANI, H.M., KHOO, C.Y. and BLOW, J.J. (1995). Purification of an MCM-containing complex as a component of the DNA replication licensing system. Nature 375: 418-421.

COLEMAN, N., MILLS, A.D. and LASKEY, R.A. (2006). Cancer Diagnosis and DNA Replication. In DNA Replication and Human Disease, M.L. DePamphilis, ed. Cold Spring Harbor Laboratory Press.

COLEMAN, T.R., CARPENTER, P.B. and DUNPHY, W.G. (1996). The Xenopus Cdc6 protein is essential for the initiation of a single round of DNA replication in cell-free extracts. Cell 87: 53-63.

COVERLEY, D., LAMAN, H. and LASKEY, R.A. (2002). Distinct roles for cyclins E and A during DNA replication complex assembly and activation. Nat Cell Biol 4: 523-528.

COX, L.S. (1992). DNA replication in cell-free extracts from Xenopuseggs is prevented by disrupting nuclear envelope function. J Cell Sci 101: 43-53.

DEWAR, J.M., BUDZOWSKA, M. and WALTER, J.C. (2015). The mechanism of DNA replication termination in vertebrates. Nature 525: 345-350.

DILWORTH, S.M., BLACK, S.J. and LASKEY, R.A. (1987). Two complexes that contain histones are required for nucleosome assembly in vitro: role of nucleoplasmin and N1 in Xenopus egg extracts. Cell 51: 1009-1018. 
DINGWALL, C., SHARNICK, S.V. and LASKEY, R.A. (1982). A polypeptide domain that specifies migration of nucleoplasmin into the nucleus. Cell 30: 449-458.

EARNSHAW, W.C., HONDA, B.M., LASKEY, R.A. and THOMAS, J.O. (1980). Assembly of nucleosomes: the reaction involving $X$. laevis nucleoplasmin. Cell21:373-383.

FANG, F. and NEWPORT, J.W. (1991). Evidence that the G1-S and G2-M transitions are controlled by different cdc2 proteins in higher eukaryotes. Cell 66: 731-742.

GAILLARD, P.H., MARTINI, E.M., KAUFMAN, P.D., STILLMAN, B., MOUSTACCHI, E. and ALMOUZNI, G. (1996). Chromatin assembly coupled to DNA repair: a new role for chromatin assembly factor I. Cell 86: 887-896

GAMBUS, A., KHOUDOLI, G.A., JONES, R.C. and BLOW, J.J. (2011). Mcm2-7 form double hexamers at licensed origins in Xenopus egg extract. J Biol Chem 286: 11855-11864.

GANDINI ATTARDI, D., MARTINI, G., MATTOCCIA, E. and TOCCHINI-VALENTINI, G.P. (1976). Effect of Xenopus laevis oocyte extract on supercoiled simian virus 40 DNA: formation of complex DNA. Proc Natl Acad Sci USA 73: 554-558.

GAUTIER, J., MINSHULL, J., LOHKA, M., GLOTZER, M., HUNT, T. and MALLER, J.L. (1990). Cyclin is a component of maturation-promoting factor from Xenopus. Cell 60: 487-494.

GAUTIER, J., NORBURY, C., LOHKA, M., NURSE, P. and MALLER, J. (1988). Purified maturation-promoting factor contains the product of a Xenopus homolog of the fission yeast cell cycle control gene cdc2+. Cell 54: 433-439.

GILLESPIE, P.J., GAMBUS, A. and BLOW, J.J. (2012). Preparation and use of Xenopus egg extracts to study DNA replication and chromatin associated proteins. Methods 57: 203-213.

GILLESPIE, P.J., LI, A. and BLOW, J.J. (2001). Reconstitution of licensed replication origins on Xenopus sperm nuclei using purified proteins. BMC biochemistry 2: 15.

GILLESPIE, P.J., NEUSIEDLER, J., CREAVIN, K., CHADHA, G.S. and BLOW, J.J. (2016). Cell Cycle Synchronization in Xenopus Egg Extracts. Methods Mol Biol 1342: 101-147.

GORLICH, D., KOSTKA, S., KRAFT, R., DINGWALL, C., LASKEY, R.A., HARTMANN, E. and PREHN, S. (1995a). Two different subunits of importin cooperate to recognize nuclear localization signals and bind them to the nuclear envelope. Curr Biol 5: 383-392.

GORLICH, D., PREHN, S., LASKEY, R.A. and HARTMANN, E. (1994). Isolation of a protein that is essential for the first step of nuclear protein import. Cell79: 767-778.

GORLICH, D., VOGEL, F., MILLS, A.D., HARTMANN, E. and LASKEY, R.A. (1995b). Distinct functions for the two importin subunits in nuclear protein import. Nature 377: $246-248$

GROS, J., DEVBHANDARI, S. and REMUS, D. (2014). Origin plasticity during budding yeast DNA replication in vitro. EMBO J 33: 621-636.

GURDON, J.B., LANE, C.D., WOODLAND, H.R. and MARBAIX, G. (1971). Use of frog eggs and oocytes for the study of messenger RNA and its translation in living cells. Nature 233: 177-182.

HELLER, R.C., KANG, S., LAM, W.M., CHEN, S., CHAN, C.S. and BELL, S.P. (2011). Eukaryotic origin-dependent DNA replication in vitro reveals sequential action of DDK and S-CDK kinases. Cell 146: 80-91.

HODGSON, B., LI, A., TADA, S. and BLOW, J.J. (2002). Geminin becomes activated as an inhibitor of Cdt1/RLF-B following nuclear import. Curr Biol 12: 678-683.

JACKSON, A., LASKEY, R.A. and COLEMAN, N. (2013). Replication proteins and human disease. In DNA Replication, 3rd Edition., S.D. Bell, M. Mechali, and M.L. DePamphilis, eds. Cold Spring Harbor Laboratory Press.

JARES, P. and BLOW, J.J. (2000). Xenopus cdc7 function is dependent on licensing but not on XORC, XCdc6, or CDK activity and is required for XCdc45 loading Genes Dev 14: 1528-1540.

KLEINSCHMIDT, J.A., FORTKAMP, E., KROHNE, G., ZENTGRAF, H. and FRANKE, W.W. (1985). Co-existence of two different types of soluble histone complexes in nuclei of Xenopus laevis oocytes. J Biol Chem 260: 1166-1176.

KLEINSCHMIDT, J.A. and FRANKE, W.W. (1982). Soluble acidic complexes containing histones $\mathrm{H} 3$ and $\mathrm{H} 4$ in nuclei of Xenopus laevis oocytes. Cell 29: 799-809.

KRUDE, T., JACKMAN, M., PINES, J. and LASKEY, R.A. (1997). Cyclin/Cdk-dependent initiation of DNA replication in a human cell-free system. Cell 88: 109-119.

KUBOTA, Y., MIMURA, S., NISHIMOTO, S., MASUDA, T., NOJIMA, H. and TAKISAWA, $\mathrm{H}$. (1997). Licensing of DNA replication by a multi-protein complex of MCM/P1 proteins in Xenopus eggs. EMBO J 16: 3320-3331.

KUBOTA, Y., MIMURA, S., NISHIMOTO, S., TAKISAWA, H. and NOJIMA, H. (1995).
Identification of the yeast MCM3-related protein as a component of Xenopus DNA replication licensing factor. Cell 81: 601-609.

KUBOTA, Y., TAKASE, Y., KOMORI, Y., HASHIMOTO, Y., ARATA, T., KAMIMURA Y., ARAKI, H. and TAKISAWA, H. (2003). A novel ring-like complex of Xenopus proteins essential for the initiation of DNA replication. Genes Dev 17: 1141-1152.

KUMAGAI, A., SHEVCHENKO, A., SHEVCHENKO, A. and DUNPHY, W.G. (2010) Treslin collaborates with TopBP1 in triggering the initiation of DNA replication. Cell 140: 349-359.

LASKEY, R.A., HONDA, B.M., MILLS, A.D. and FINCH, J.T. (1978). Nucleosomes are assembled by an acidic protein which binds histones and transfers them to DNA. Nature 275: 416-420.

LASKEY, R.A., MILLS, A.D. and MORRIS, N.R. (1977). Assembly of SV40 chromatin in a cell-free system from Xenopus eggs. Cell 10: 237-243.

LENO, G.H., MILLS, A.D., PHILPOTT, A. and LASKEY, R.A. (1996). Hyperphosphorylation of nucleoplasmin facilitates Xenopus sperm decondensation at fertilization. J Biol Chem 271: 7253-7256.

LI, A. and BLOW, J.J. (2005). Cdt1 downregulation by proteolysis and geminin inhibition prevents DNA re-replication in Xenopus. EMBO J 24: 395-404.

LOHKA, M.J., HAYES, M.K. and MALLER, J.L. (1988). Purification of maturationpromoting factor, an intracellular regulator of early mitotic events. Proc Natl Acad Sci USA 85: 3009-3013.

LOHKA, M.J. and MASUI, Y. (1983). Formation in vitro of sperm pronuclei and mitotic chromosomes induced by amphibian ooplasmic components. Science 220: 719-721.

LOHKA, M.J. and MASUI, Y. (1984a). Effects of Ca2+ ions on the formation of metaphase chromosomes and sperm pronuclei in cell-free preparations from unactivated Rana pipiens eggs. Dev Biol 103: 434-442.

LOHKA, M.J. and MASUI, Y. (1984b). Roles of cytosol and cytoplasmic particles in nuclear envelope assembly and sperm pronuclear formation in cell-free preparations from amphibian eggs. J Cell Biol 98: 1222-1230.

MADINE, M.A., KHOO, C.Y., MILLS, A.D., MUSAHL, C. and LASKEY, R.A. (1995) The nuclear envelope prevents reinitiation of replication by regulating the binding of MCM3 to chromatin in Xenopus egg extracts. Curr Biol 5: 1270-1279.

MAIORANO, D., MOREAU, J. and MECHALI, M. (2000). XCDT1 is required for the assembly of prereplicative complexes in Xenopus laevis. Nature 404: 622-625.

MATHEWS, M. and KORNER, A. (1970). Mammalian cell-free protein synthesis directed by viral ribonucleic acid. Eur J Biochem 17: 328-338

MATTOCCIA, E., ATTARDI, D.G. and TOCCHINI-VALENTINI, G.P. (1976). DNArelaxing activity and endonuclease activity in Xenopus laevis oocytes. Proc Nat Acad Sci USA 73: 4551-4554.

MCGARRY, T.J. and KIRSCHNER, M.W. (1998). Geminin, an inhibitor of DNA replication, is degraded during mitosis. Cell 93: 1043-1053.

MECHALI, M. and HARLAND, R.M. (1982). DNA synthesis in a cell-free system from Xenopus eggs: priming and elongation on single-stranded DNA in vitro. Cell 30: 93-101.

NEWPORT, J. (1987). Nuclear reconstitution in vitro: stages of assembly around protein-free DNA. Cell 48: 205-217.

OHSUMI, K. and KATAGIRI, C. (1991). Characterization of the ooplasmic factor inducing decondensation of and protamine removal from toad sperm nuclei: involvement of nucleoplasmin. Dev Biol 148: 295-305.

ON, K.F., BEURON, F., FRITH, D., SNIJDERS, A.P., MORRIS, E.P. and DIFFLEY J.F. (2014). Prereplicative complexes assembled in vitro support origin-dependent and independent DNA replication. EMBO J 33: 605-620.

PELHAM, H.R. and JACKSON, R.J. (1976). An efficient mRNA-dependent translation system from reticulocyte lysates. Eur J Biochem 67: 247-256.

PHILPOTT, A. and LENO, G.H. (1992). Nucleoplasmin remodels sperm chromatin in Xenopus egg extracts. Cell 69: 759-767.

PHILPOTT, A., LENO, G.H. and LASKEY, R.A. (1991). Sperm decondensation in Xenopus egg cytoplasm is mediated by nucleoplasmin. Cell 65: 569-578.

ROBBINS, J., DILWORTH, S.M., LASKEY, R.A. and DINGWALL, C. (1991). Two interdependent basic domains in nucleoplasmin nuclear targeting sequence: identification of a class of bipartite nuclear targeting sequence. Cell 64: 615-623.

ROMANOWSKI, P., MADINE, M.A., ROWLES, A., BLOW, J.J. and LASKEY, R.A. (1996). The Xenopus origin recognition complex is essential for DNA replication and MCM binding to chromatin. Curr Biol 6: 1416-1425. 
ROWLES, A., CHONG, J.P., BROWN, L., HOWELL, M., EVAN, G.I. and BLOW, J.J. (1996). Interaction between the origin recognition complex and the replication licensing system in Xenopus. Cell 87: 287-296.

SANGRITHI, M.N., BERNAL, J.A., MADINE, M., PHILPOTT, A., LEE, J., DUNPHY, W.G. and VENKITARAMAN, A.R. (2005). Initiation of DNA replication requires the RECQL4 protein mutated in Rothmund-Thomson syndrome. Cell 121: 887-898.

SHEEHAN, M.A., MILLS, A.D., SLEEMAN, A.M., LASKEY, R.A. and BLOW, J.J. (1988). Steps in the assembly of replication-competent nuclei in a cell-free system from Xenopus eggs. J Cell Biol 106: 1-12

TADA, S., LI, A., MAIORANO, D., MECHALI, M. and BLOW, J.J. (2001). Repression of origin assembly in metaphase depends on inhibition of RLF-B/Cdt1 by geminin. Nat Cell Biol 3: 107-113.
WALTER, J., SUN, L. and NEWPORT, J. (1998). Regulated chromosomal DNA replication in the absence of a nucleus. Mol Cell 1: 519-529.

WALTER, J.C. (2000). Evidence for sequential action of cdc7 and cdk2 protein kinases during initiation of DNA replication in Xenopus egg extracts. $J$ Biol Chem 275: 39773-39778.

WOODWARD, A.M., GOHLER, T., LUCIANI, M.G., OEHLMANN, M., GE, X., GARTNER, A., JACKSON, D.A. and BLOW, J.J. (2006). Excess Mcm2-7 license dormant origins of replication that can be used under conditions of replicative stress. $J$ Cell Biol 173: 673-683.

YEELES, J.T., DEEGAN, T.D., JANSKA, A., EARLY, A. and DIFFLEY, J.F. (2015). Regulated eukaryotic DNA replication origin firing with purified proteins. Nature 519: $431-435$

\section{Further Related Reading, published previously in the Int. J. Dev. Biol.}

Identification of the sperm motility-initiating substance in the newt, Cynops pyrrhogaster, and its possible relationship with the acrosome reaction during internal fertilization

Toshihiko Watanabe, Hideo Kubo, Shinya Takeshima, Mami Nakagawa, Manami Ohta, Saori Kamimura, Eriko Takayama-Watanabe, Akihiko Watanabe, and Kazuo Onitake

Int. J. Dev. Biol. (2010) 54: 591-597

Signalling molecules involved in mouse bladder smooth muscle cellular differentiation Benchun Liu, Dongxiao Feng, Guiting Lin, Mei Cao, Yuet Wai Kan, Gerald R. Cunha and Laurence S. Baskin Int. J. Dev. Biol. (2010) 54: 175-180

Gonad-stimulating substance-like molecule from the radial nerve of the sea cucumber Hideki Katow, Tomoko Katow and Akihiko Moriyama Int. J. Dev. Biol. (2009) 53: 483-491

The influence of mouse sera, regenerating liver extracts and bacterial products on the abilities of different cells in vitro. N Zarkovic, M Osmak, D Novak, N Lers and M Jurin Int. J. Dev. Biol. (1991) 35: 239-249

Hormonal factors from the mammalian pineal gland interfere with cell development in Hydra. W A Müller, C Bartsch, H Bartsch, I Maidonis and E Bayer Int. J. Dev. Biol. (1998) 42: 821-824
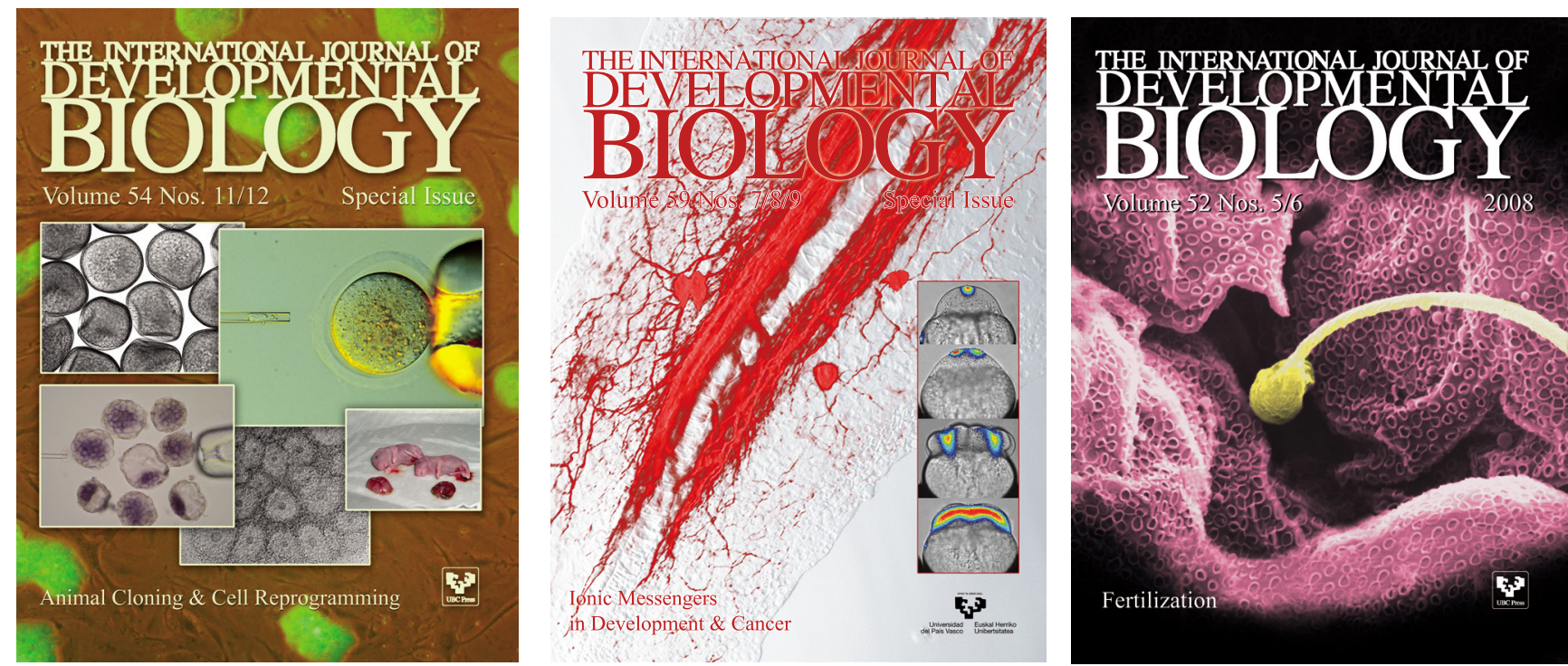